\title{
Polyacrylamide disc electrophoresis of the proteins of cerebrospinal fluid and brain
}

\author{
GUY MONSEU ${ }^{1}$ AND J. N. CUMINGS \\ From the Department of Chemical Pathology, The Institute of Neurology, The National Hospital, \\ Queen Square, London.
}

Since one of us (J.N.C.) in 1953 recorded the results of electrophoresis on paper of the proteins of the cerebrospinal fluid and cerebral cyst fluids a number of other supporting media have been employed for this purpose. Some, such as starch, are valuable because of a higher resolving power and a greater ability to separate many of the protein components. The use of the polyacrylamide disc electrophoretic technique of Ornstein and Davis (1962) has been introduced recently and it offered a fresh opportunity to study cerebrospinal fluid and brain proteins by a method which appeared to possess certain advantages over other techniques. This paper records such a study and the results are compared with the findings of other workers using different techniques as well as that of Cunningham (1964) who examined the cerebrospinal fluid with the same method.

The method has also been employed for the detection of enzymes, especially lactate dehydrogenase, and of caeruloplasmin.

\section{METHODS AND MATERIAL}

Cerebrospinal fluid was obtained by lumbar puncture from 100 subjects and kept at $-20^{\circ} \mathrm{C}$. until used. No organic neurological disease was present in 30 and in each the cerebrospinal fluid protein was less than $40 \mathrm{mg}$. per $100 \mathrm{ml}$. with less than 4 lymphocytes per c.mm.; these were classed as control fluids. Cerebrospinal fluid from 70 subjects with a variety of organic neurological disorders, some of which are mentioned below, all showed a raised protein level and constitute the second group. Concentration of the cerebrospinal fluid using negative pressure and a collodion filtration shell was carried out on a few occasions.

Disc electrophoresis was carried out by the method of Ornstein and Davis (1962) with these additional particulars. The electrophoresis was carried out in $110 \mathrm{~mm}$. tubes filled to a height of $60 \mathrm{~mm}$. with 'small-pore gel'. After the gel became solid, in about 45 minutes, an amount of 'large-pore gel' was added to make an additional height of $10 \mathrm{~mm}$; ; eight to 12 specimens were examined at the same time with a current of $3 \mathrm{~mA}$. per

'Present address: Institut médico-chirurgical d'Ixelles, rue J. Pacot, Brussels, Belgium tube for about 100 minutes, the actual time being determined by the rate of migration towards the cathode of the indicator bromphenol blue. A quantity of cerebrospinal fluid containing from 150 to $400 \mu \mathrm{g}$. of protein in a volume varying from 0.1 to $0.75 \mathrm{ml}$. was thoroughly mixed with sucrose to give a final concentration of $25 \%$ sucrose and layered over the large-pore gel ('spacer gel') by means of an Agla micrometer syringe (Ornstein and Davis modified by Fox, Thurman, and Boulter, 1963).

The gels were stained with $1 \%$ naphthalene black in $7 \%$ acetic acid, and the excess stain removed by frequent washings in $7 \%$ acetic acid, or electrophoretically, both methods giving identical results.

Reproducibility was tested by putting up the same cere? brospinal fluid in many tubes at both the same concen? tration as well as at varying concentrations of protein content.

Sera were examined by the same technique after dilue tion in distilled water to give a protein concentration of 300 to $500 \mu \mathrm{g}$. per $0.5 \mathrm{ml}$. which was then used in a manner similar to that for cerebrospinal fluid. The sers were from the same patients from whom the cerebro= spinal fluids were obtained.

Specimens of cerebral tissue were obtained at necropsy performed less than six hours after death. White matter and cortex were separated from different areas of the brain and the soluble cerebral proteins extracted with 0.3 M sucrose (Cumings, 1961). The clear centrifuged extracts were diluted to give a final concentration of protein of $500 \mu \mathrm{g}$. per $0.5 \mathrm{ml}$. before use.

The gels were also stained for caeruloplasmin using $p$-phenylenediamine in acetate buffer (Uriel, 1958) and for the isoenzymes of lactate dehydrogenase (Yakulis, Gibson, and Heller, 1962).

\section{RESULTS}

An illustration of actual results in serum and normal cerebrospinal fluid of one patient, the cerebrospinal fluid in a case of polyneuritis, and of cerebral white matter is given in Figure 1.

Drawings to scale of all the individual discs were made but because variations of time, length of gel, and temperature alter the actual distance of travel of albumin from the origin it was considered desirable to reduce them all to a constant length. This distance was fixed as $100 \mathrm{~mm}$. from the slowest 


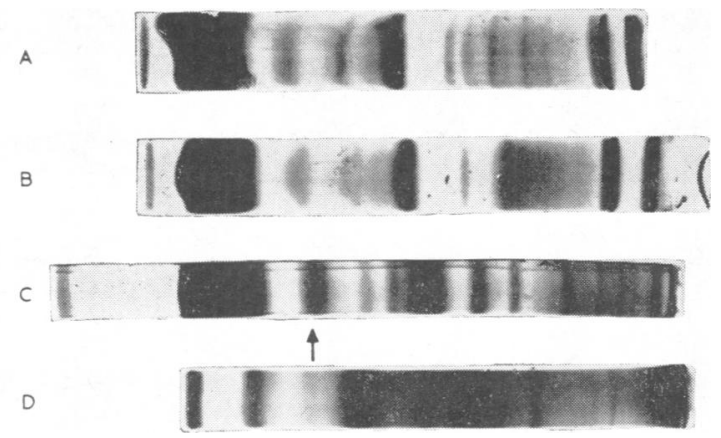

FIG. 1. Photograph of 4 polyacrylamide gel discs of (A) serum (300 $\mu \mathrm{g}$. protein); (B) normal cerebrospinal fluid (250 $\mu$ g. protein); $(C)$ cerebrospinal fluid from a case of polyneuritis $(350 \mu \mathrm{g}$. protein): the arrow indicates the fast a globulin band which is increased in amount; and (D) white matter of the parietal lobe $(500 \mu \mathrm{g}$. protein $)$.

CSF 1

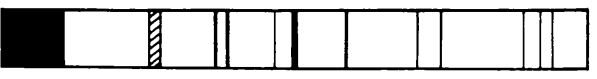

SERUM

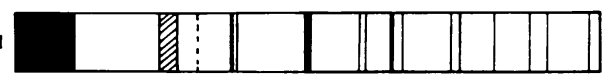

CSF 2

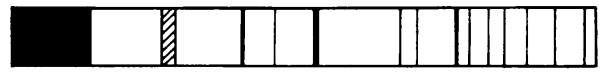

SERUM 2

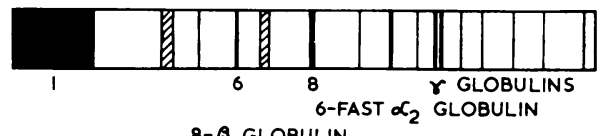

FIG. 2. Drawings to demonstrate the comparison between the electrophoretic patterns of normal serum and normal cerebrospinal fluid, each pair being from the same patient (300 $\mu \mathrm{g}$. of protein). $\gamma$ globulin to the most anodic edge of albumin. The centre of each band was measured from the front edge of the albumin and plotted. Examples of the electrophoretic patterns of sera and cerebrospinal fluids from two patients so drawn are illustrated in Figure 2.

Table I records the results of the cerebrospinal fluid examination in the 30 control cases, in nine examples of multiple sclerosis, seven of polyneuritis, and 10 of cerebral tumour. Included in the table is the distance of travel, the frequency and the relative intensity ( 1 to 3 ) of each band, numbering them from albumin (1) to the least mobile $\gamma$ globulin (14).

Figure 3 is a drawing of one example of each of the cases recorded in Table I.

Recordings of disc electrophoresis of two control cerebrospinal fluids have been made and compared with those obtained by Cunningham (1964) and the results are exactly comparable.

The soluble cerebral proteins of the frontal, parietal, temporal, and occipital areas of two brains have been examined and in general the patterns of either white matter or cortex from each area have been similar, but those of white matter differ from those of the cortex. Some 15 separate bands in all areas were obtained.

The results obtained on polyacrylamide gel have been compared with those obtained by starch electrophoresis for normal sera, for normal cerebrospinal fluid (Kutt, McDowell, Chapman, Pert, and Hurwitz, 1960), and for the soluble cerebral proteins (Cumings, 1961). Figure 4 shows these findings, all the patterns having been drawn to the same scale.

Some general comments are necessary relating to these findings. Using different concentrations of protein in eight separate fluids there was complete

TABLE I

RESULTS IN THE CEREBROSPINAL FLUIDS EXAMINED

Normal Cerebrospinal Fluid (30 cases) Multiple Sclerosis ( 9 cases)

Polyneuritis ( 7 cases)

Cerebral Tumour (10 cases)

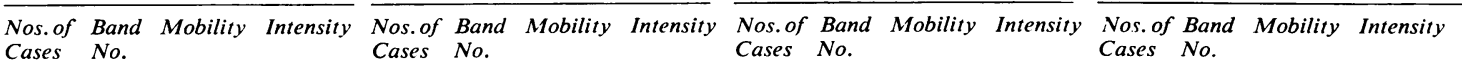

Cases No.

Cases No.

\begin{tabular}{|c|c|c|c|c|c|c|c|c|c|c|c|c|c|c|c|}
\hline 30 & 1 & 3.9 & 3 & 9 & 1 & 4 & 3 & 7 & 1 & $4 \cdot 7$ & 3 & 10 & 1 & 5 & 3 \\
\hline 18 & 2 & $19 \cdot 7$ & 1 & 5 & 2 & 15 & 1 & 7 & 2 & $22 \cdot 3$ & $2 \cdot 5$ & 6 & 2 & $16 \cdot 6$ & 1 \\
\hline 24 & 3 & 25 & 1 & 7 & 3 & 23 & 1 & 5 & 3 & $25 \cdot 1$ & 1 & 10 & 3 & 24 & 1 \\
\hline 14 & 4 & 31 & 1 & - & - & - & - & 6 & 4 & $30 \cdot 2$ & 1 & 8 & 4 & $30 \cdot 3$ & 1 \\
\hline 17 & 5 & $35 \cdot 6$ & 1 & 7 & 5 & $34 \cdot 2$ & 1 & 4 & 5 & $35 \cdot 2$ & 1 & 6 & 5 & $37 \cdot 1$ & 1 \\
\hline 26 & 6 & $39 \cdot 6$ & 2 & 9 & 6 & $40 \cdot 3$ & 2 & $\begin{array}{l}7 \\
5\end{array}$ & $\begin{array}{l}6 \\
6 a\end{array}$ & $\begin{array}{l}40 \cdot 4 \\
42\end{array}$ & $\begin{array}{l}2 \\
1\end{array}$ & 8 & 6 & $40 \cdot 8$ & 2 \\
\hline 22 & 7 & $45 \cdot 6$ & 1 & 5 & 7 & $45 \cdot 3$ & 1 & 5 & 7 & $47 \cdot 5$ & 1 & 6 & 7 & $45 \cdot 4$ & 1 \\
\hline 30 & 8 & 50 & 3 & 9 & 8 & 50 & 3 & 7 & 8 & $50 \cdot 9$ & 3 & 10 & 8 & $50 \cdot 2$ & 3 \\
\hline 27 & 9 & $60 \cdot 5$ & 2 & 9 & 9 & $60 \cdot 5$ & 2 & 7 & 9 & $60 \cdot 9$ & 2 & 10 & 9 & $60 \cdot 3$ & 2 \\
\hline 30 & 10 & 75 & 1 & 9 & 10 & $74 \cdot 9$ & 1 & 7 & 10 & $75 \cdot 6$ & 1 & 10 & 10 & $73 \cdot 7$ & 1 \\
\hline 14 & 11 & $81 \cdot 3$ & 1 & 4 & 11 & $81 \cdot 1$ & 1 & 5 & 11 & 80.7 & $1 \cdot 5$ & 8 & 11 & $81 \cdot 4$ & 1 \\
\hline 16 & 12 & 87 & 1 & 5 & 12 & $87 \cdot 5$ & 1 & 4 & 12 & $87 \cdot 2$ & $1 \cdot 5$ & 7 & 12 & $86 \cdot 7$ & 1 \\
\hline 13 & 13 & $92 \cdot 1$ & 1 & 6 & 13 & 93.5 & 1 & 5 & 13 & $93 \cdot 5$ & $1 \cdot 5$ & 8 & 13 & 92.4 & 1 \\
\hline 24 & 14 & $97 \cdot 8$ & 1 & 8 & 14 & 96.5 & 1 & 6 & 14 & $97 \cdot 9$ & $1 \cdot 5$ & 8 & 14 & $97 \cdot 4$ & 1 \\
\hline
\end{tabular}

Band $1=$ albumin $\quad$ Band $6=$ fast $a_{2}$ globulin Band $8=\beta$ globulin Bands 10-14 $=\gamma$ globulins 


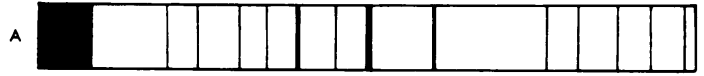

8

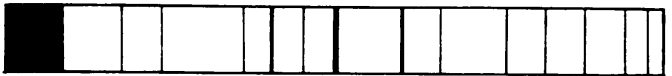

c

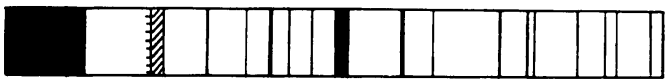

D

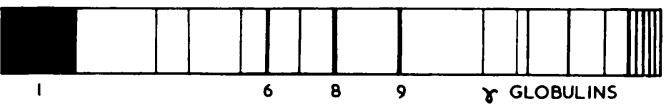

FIG. 3. The electrophoretic pattern of cerebrospinal fluids from (A) normal (150 $\mu$ g. protein); (B) multiple sclerosis (260 $\mu$ g. protein); $(C)$ polyneuritis (350 $\mu \mathrm{g}$. protein); and (D) a patient with an astrocytoma $(240 \mu \mathrm{g}$. protein).

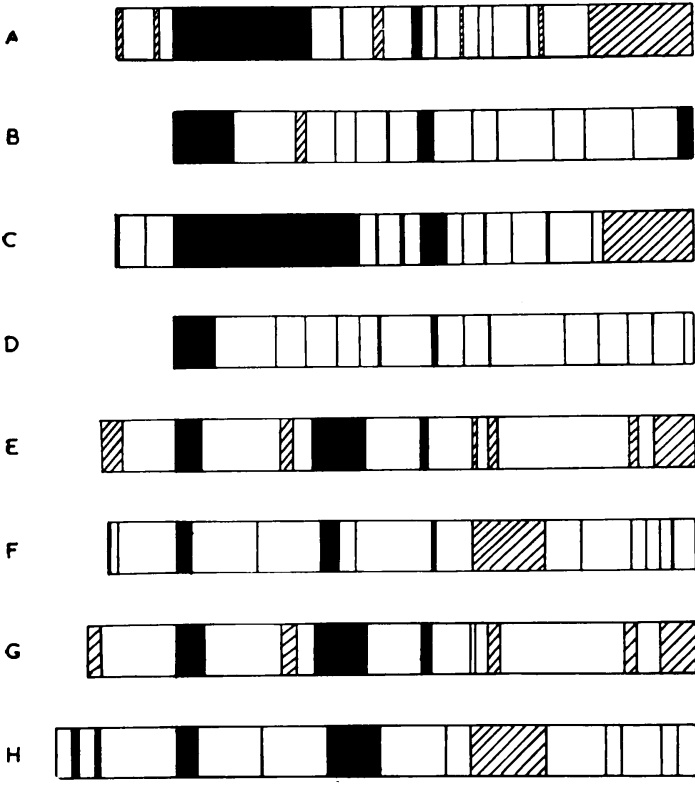

FIG. 4. A comparison between the electrophoretic patterns obtained in starch $(A, C, E, G)$ and in polyacrylamide $(B, D, F, H) . \quad A$ and $B$ normal serum, $C$ and $D$ normal cerebrospinal fluid, $E$ and $F$ soluble cerebral proteins of the parietal white matter, and $G$ and $H$ of the parietal cortex.

reproducibility and the relative intensity of the different bands remained constant. This in part is due to the use of unconcentrated cerebrospinal fluid as was found previously by Cunningham (1964). It has always been suspected that significant variation could take place when concentration of cerebrospinal fluid was performed under a variety of conditions.
The control or normal cerebrospinal fluids $z$ showed on average 14 bands with a few showing $\stackrel{\Phi}{=}$ nine and a few as many as 17. Pre-albumin was definitely present on five occasions but the site of this protein is also the area to which the bromphenol ${ }^{\circ}$ blue migrates thus obscuring the pre-albumin band, as was found by omitting the dye from a series of $\frac{\rho}{5}$ electrophoretic runs. In addition to the deeply stained albumin band there was a central band₹ (number 8), which both by comparison with the results of others and by the use of siderophyllin was $\stackrel{?}{\stackrel{9}{+}}$ a $\beta$ globulin. Between albumin and $\beta$ globulin, five bands were usually present, band 6 being most in- 흘 tense and most frequent and corresponding to $\frac{\bar{\rho}}{\partial}$ fast $\alpha_{2}$ globulin of starch electrophoresis. At the $\stackrel{\mathbb{Q}}{\mathbb{Q}}$ cathodic end there were a group of up to seven distinct $\gamma$ globulin bands with an average of five bands. This area represents about one quarter of the whole? length. Between the $\beta$ globulin and the $\gamma$ globulins $\vec{\omega}$ one to four bands were found, one (no. 9) being 9 encountered with great regularity, while band $10 \overline{\widehat{z}}$ probably represents the slow $\alpha_{2}$ globulin of starch? electrophoresis of serum (Smithies, 1955).

The electrophoretic patterns of the cerebre $\overrightarrow{-}$ spinal fluid from neurological diseases showed less variation from the normal than had been expected 응 The nine cases of multiple sclerosis, including tw with a strong paretic Lange curve, showed onfy minor differences, as in the case in which there were응 more deeply staining $\gamma$ globulin bands. No abnormal bands were present in any case. Similar findings, that there is some increase in intensity of the $\gamma$ globudin $\overrightarrow{0}$ bands, were found in other conditions, particularfy in seven cases of cerebral or cerebellar tumour, and in a case of sarcoidosis.

However, in seven cases of polyneuritis changes in pattern and intensity were seen (Table I and Fig. 1), for in every case band 2, a fast $\alpha$ globulin, was deeplyo stained and in one patient there was also a parallel 0 increase in the $\alpha_{2}$ globulin in the serum. There was a $\overrightarrow{\overrightarrow{0}}$ small but significant increase in $\gamma$ globulins in the 3 cases examined as there was in three cases of widespread secondary carcinomatosis. Ten cases of? primary cerebral tumour failed to show any variation from the normal pattern apart from the increase in $\gamma$ globulins in three cases.

Presenile dementia ( 2 cases), cortical atrophy? (6 cases), and benign intracranial hypertension ( 48 cases) showed no important differences from the normal.

\section{DISCUSSION}

It is not easy to make a direct comparison of the findings described here with the results of authorso using agar (Lowenthal and Petre-Quadens, 1963) 
although it is simpler to make a comparison with starch electrophoresis of cerebrospinal fluid (Kutt et al., 1960) and the results obtained by Cunningham (1964). Nevertheless the results presented are similar in many respects as, for example, in that all methods yield one or two pre-albumins, a strong albumin band, which in starch tends to be of greater length thus obscuring an $\alpha$ globulin, and a wellmarked, centrally placed $\beta$ globulin, demonstrated in agar by Wieme (1959) and Lowenthal and PetreQuadens (1963). Other constant bands in starch and polyacrylamide are the fast $\alpha_{2}$ globulin (band 6), and by all three methods band 9 in these experiments which corresponds to band 10 of Cunningham and band $\bar{\imath}$ of Lowenthal and Petre-Quadens. Bands 11 and 12 of Cunningham were only found in $36 \%$ and the fast $\alpha_{2}$ described by Kutt et al. (1960) was present in $87 \%$ of our cases.

There were some differences in the patterns shown in electrophoresis of serum between starch and polyacrylamide as can be seen well illustrated in Fig. 4, these being chiefly the absence of the faster $\alpha$ globulin and the presence of more $\alpha \beta$ bands in starch as compared with polyacrylamide.

There is a striking difference in the fewer number of bands of $\gamma$ globulin in serum as compared with cerebrospinal fluid and this needs further investigation, while additional studies on soluble brain proteins with a comparison of the blood and cerebrospinal fluid protein patterns from the same patient may be of assistance in determining the possible site or source of origin of the cerebrospinal fluid $\gamma$ globulins.

The method of electrophoresis using polyacrylamide gel as described here has been found to be valuable in the study of body proteins, for the results are reproducible, permanent for they can be stored in small plastic containers, and there is a resolving power superior to any other method with the possible exception of starch gel. A further considerable advantage is that, especially with regard to the cerebrospinal fluid, no concentration is required or even desirable unless the total protein content is $20 \mathrm{mg}$. per $100 \mathrm{ml}$. or less. Enzymes such as lactate dehydrogenase as well as caeruloplasmin can be readily visualized. In this regard, however, it is not possible to solubilize or re-extract out of the gel these enzymes or the protein component as it is in starch electrophoresis (Cumings, 1961; 1962). Quantitative measurements using polyacrylamide gel have not yet been possible but alterations in technique such as allowing a longer time of electrophoresis with a greater length of disc may overcome scanning difficulties.

The general patterns obtained by the three main techniques-agar, starch, and polyacrylamide gel- are very similar even though some differences do exist. One for instance is the spreading of the albumin band seen in starch. Yet a comparison between serum and cerebrospinal fluid by these methods leads to the conclusion that albumin and the $\alpha$ and $\beta$ globulins are very similar both in site and in relative amount. The $\gamma$ globulins, however, differ in many aspects.

There is some disagreement concerning the interpretation of the pherograms in pathological conditions. Many studies using agar have been undertaken to show a correlation between disease and protein pattern (Lowenthal and Petre-Quadens, 1963; Laterre, Heremans, and Demanet, 1962). The experiments recorded here do not support this degree of close correlation more especially in multiple sclerosis, even though changes were found in polyneuritis, more especially an increase in a fast $\alpha$ globulin (band 2). A similar pattern was noticed in cases of carcinomatosis and in a case of acute poliomyelitis, as was also found by Laterre et al. (1962), while increases of $\gamma$ globulin were found in sarcoidosis and some tumour cases.

The finding in the soluble cerebral proteins of two or generally three pre-albumin fractions, and a total of some 15 bands is in general agreement with previous studies (Cumings, 1961; 1962). Further study of such proteins in more cases with the application of various enzyme stains to such gels will be rewarding.

\section{SUMMARY}

Polyacrylamide disc electrophoresis has been performed on a series of 100 cerebrospinal fluids, from serum, and from sucrose extracts of cerebral tissue. A normal pattern is described together with the results obtained from the cerebrospinal fluid from cases of a number of different diseases.

A comparison between results from starch electrophoresis and the present technique is made together with comments relating to the lack of specific changes in some conditions, notably multiple sclerosis. Preliminary studies on the soluble cerebral proteins are mentioned and an indication given that both these and the unusually large number of $\gamma$ globulins present in the cerebrospinal fluid need further examination.

Enzyme localization has been shown to be possible.

One of us (G.M.) has been in receipt of a grant from the Ministry of National Education, Belgium, for which thanks are expressed. We are also grateful for the assistance of Mr. R. Shortman, Mr. J. M. Mills, and the Department of Medical Photography, Institute of Neurology (Queen Square). 


\section{REFERENCES}

Cumings, J. N. (1953). The examination of the cerebrospinal fluid and cerebral cyst fluid by paper strip electrophoresis. J. Neurol. Neurosurg. Psychiat., 16, 152-157.

(1961). Soluble cerebral proteins in normal and oedematous brain. J. clin. Path., 14, 289-294.

- (1962). Water soluble proteins and enzymes in normal and in oedematous brain tissue. In Proceedings of 4th international Congress of Neuropathology, 1961, München, edited by $\mathrm{H}$. Jacob, vol. I, pp. 157-161. Thieme, Stuttgart.

Cunningham, V. R. (1964). Analysis of 'native' cerebrospinal fluid by the polyacrylamide disc electrophoresis technique. J. clin. Path., 17, 143-148.

Fox, D. J., Thurman, D. A., and Boulter, D. (1963). Electrophoresis of plant proteins in polyacrylamide gels. Biochem. J., 87, 29P-30P.

Kutt, H., McDowell, F., Chapman, L., Pert, J. H., and Hurwitz, L. J. (1960). Abnormal protein fractions of cerebrospinal fluid demonstrated by starch gel electrophoresis. Neurology (Minneap.), 10, 1064-1067.

Laterre, E. C., Heremans, J. F., and Demanet, G. (1962). La pathologie des protéines du liquide céphalo-rachidien. Etude électro- phorétique et immuno-électrophorétique (600 observations). Rev. neurol., 107, 500-521.

Lowenthal, A., and Petre-Quadens, O. (1963). Intérêt de l'électrophorèse en agar des protéines du liquide céphalo-rachidien pour l'établissement du diagnostic différentiel en neurologie. Rev. franc. Étud. clin. biol., 8, 255-263.

Ornstein, L., and Davis, B. J. (1962). Disc Electrophoresis. Part I (Theory) by L. Ornstein. Part II (Material and Methods) by $\Omega$ B. J. Davis. Preprinted by Distillation Products Industries (Division of Eastman Kodak Company) prior to journal $\stackrel{\text { a }}{\overrightarrow{2}}$ publication. Rochester, New York; Kirkby, Liverpool.

Smithies, O. (1955). Zone electrophoresis in starch gels: group variations in the serum proteins of normal human adults. Biochem.
$J ., 61,629-641$.

Uriel, J. (1958). Colorimetric detection of human caeruloplasmin $\square$ oxidase activity after electrophoresis in agar plates or after immuno-electrophoresis. Nature (Lond.), 181, 999-1000.

Wieme, R. J. (1959). Studies on Agar Gel Electrophoresis. Arscia $\frac{\text { क }}{7}$ Uitgaven, N.V., Brussels.

Yakulis, V. J., Gibson, C. W., and Heller, P. (1962). Agar gel electrophoresis for the determination of isozymes of lactic and malic dehydrogenase. Amer. J. clin. Path., 38, 378-382.

\section{The December 1964 Issue}

\section{THE DECEMBER 1964 ISSUE CONTAINS THE FOLLOWING PAPERS}

Immunological disturbances in myasthenia gravis with a report of Hashimoto's disease developing after thymectomy JOHN A. SIMPSON

Acute haemorrhagic leucoencephalitis (Hurst) with a concurrent primary herpes simplex infection ALBERT N. MARTINS, LUDWIG G. KEMPE, and GEORGE J. HAYES

Follow-up study of spinal accessory-facial nerve anastomosis with special reference to the electromyographic findings C-A. THULIN, I. PETERSÉN, and L. GRANHOLM

Cortical dysarthria and dysprosody of speech C. W. M. WHITTY

Changing effects of frontal lesions in man AARON SMITH

Psychological aspects of diencephalotomy M. F. JURKO and 0. J. ANDY

Clinical studies of multiple sclerosis in Israel Part II A comparison between European and Afro-Asian patients MILTON ALTER, URI LEIBOWITZ, and LIPMAN HALPERN

Leucoencephalopathy after portacaval anastomosis in a patient with hepatic cirrhosis D. L. GARDNER, A. I. $\mathbf{S}$. MACPHERSON, A. F. J. MALONEY, and J. RICHMOND

Response to treatment with chelating agents of anaemia, chronic encephalopathy, and myelopathy due to lead poisoning J. A. SIMPSON, D. A. SEATON, and J. F. ADAMS
Encephalopathy following a sting BRYAN ASHWORTH

Bilateral internal carotid artery occlusion secondary closed head injuries DAVID YASHON, A. B. JOHNSON, and JOHN A. JANE

Brain abscess due to Streptomyces griseus P. R. $\vec{R}$. O CLARKE, G. B. R. WARNOCK, R. BLOWERS, and MARGARET WILKINSON

Quality of survival in treated patients with supratentorial gliomata M. J. BETTY

Multiple myeloma with polyneuropathy and osteosclerotic lesions A. AGUAYO, D. W. THOMPSON, and J. G. HUMPHREY

Posterior scalloping of vertebral bodies in uncontrolled hydrocephalus C. NORMAN SHEALY, MARJORIE LEMAY, and FUAD $S$. HADDAD

Site of action of 'intravenous regional anaesthesia' D. w. MILES, J. L. JAMES, D. E. CLARK, and J. G. WHITWAM

Proceedings of the Society of British Neurological

Surgeons: 69 th meeting

Book reviews

Index to volume XXVII

Copies are still available and may be obtained from the PUBLISHING MANAGER, BRITISH MEDICAL ASSOCIATION, TAVISTOCK SQUARE, W.C.I, price 18s. 6D. 